\title{
Correction to: Contrasting perspectives on the Lava Creek Tuff eruption, Yellowstone, from new $\mathrm{U}-\mathrm{Pb}$ and ${ }^{40} \mathrm{Ar} /{ }^{39} \mathrm{Ar}$ age determinations
}

\author{
Colin J. N. Wilson ${ }^{1} \cdot$ Mark E. Stelten $^{2}$ • Jacob B. Lowenstern ${ }^{2}$
}

Published online: 18 June 2018

(C) Springer-Verlag GmbH Germany, part of Springer Nature 2018

Correction to: Bulletin of Volcanology (2018) 80:53

https://doi.org/10.1007/s00445-018-1229-x

The following statement was omitted from the acknowledgments section of the manuscript but is included now in accordance with U.S. Geological Survey policy. Any use of trade, firm, or product names is for descriptive purposes only and does not imply endorsement by the U.S. Government.

The online version of the original article can be found at https://doi.org/ 10.1007/s00445-018-1229-x

Colin J. N. Wilson

colin.wilson@vuw.ac.nz

1 School of Geography, Environment and Earth Sciences, Victoria University of Wellington, P.O. Box 600, Wellington 6140, New Zealand

2 U.S. Geological Survey, Mailstop 910, 345 Middlefield Road, Menlo Park, CA 94025, USA 